\title{
Water Quality Index (WQI) of Jaguari and Atibaia Rivers in the region of Paulínia, São Paulo, Brazil
}

\author{
Marcio Antonio Gomes Ramos • Eduardo Schneider Bueno de Oliveira • \\ Antonio Carlos Simões Pião • Dilza Aparecida Nalin de Oliveira Leite • \\ Dejanira de Franceschi de Angelis
}

Received: 14 May 2015 / Accepted: 22 March 2016/Published online: 1 April 2016

(C) Springer International Publishing Switzerland 2016

\begin{abstract}
Due to the concern with the quality of hydric resources, the monitoring is essential to evaluate and identify the anthropogenic and environmental interferences in a quantitative and qualitative level. In order to assist the interpretation of the water status of hydric bodies, the gathering of analytical data often considers the Water Quality Index (WQI). This index transforms technical information in description of the water quality status, highlighting the effectiveness of its use and guiding the decision-making process when necessary. The aim of this research is to assess the water quality of a region in São Paulo State, Brazil, by means of the WQI
\end{abstract}

M. A. G. Ramos $(\bowtie) \cdot$ D. A. Nalin de Oliveira Leite •

D. de Franceschi de Angelis

Department of Biochemistry and Microbiology, Institute of Biosciences, Universidade Estadual Paulista Júlio de Mesquita Filho UNESP, Avenida 24A, 1515-Bela Vista, CEP

13506-900 Rio Claro, SP, Brazil

e-mail: marciogr@rc.unesp.br

D. A. Nalin de Oliveira Leite

e-mail: dilzanalin@hotmail.com

D. de Franceschi de Angelis

e-mail: dangelis@rc.unesp.br

E. S. Bueno de Oliveira

Department of Biostatistics, Institute of Biosciences, UNESP/

Rubião Junior, Botucatu, SP, Brazil

e-mail: eduardosb@ibb.unesp.br

A. C. S. Pião

Department of Statistics, Applied Mathematics and Computer Science, Institute of Geosciences, UNESP, Rio Claro, SP, Brazil e-mail: piao@rc.unesp.br of Jaguari and Atibaia Rivers. The period of intense drought, which affected the Brazilian southeast in 2014, was evaluated and compared to the mean values recorded from October 2009 to March 2015, correlating the values of Escherichia coli and the biochemical oxygen demand (BOD). One hundred nine samples were collected, being 53 from dry seasons, between October and March, and 56 from rainy seasons, between April and September. The WQIs in Jaguari and Atibaia Rivers, during dry season, were of 42.2 (medium) and 36.7 (bad), respectively. The same pattern was registered for the dry season, for both rivers, with indices values of 40.1 for Jaguari River (medium) and 34.9 for Atibaia River (bad). This research presented the need of an effective evaluation of the environmental quality and preservation by competent organs for both rivers. Due to the detected conditions, special attention should be given to the Atibaia River.

Keywords Water quality index $\cdot$ Escherichia coli . Biochemical oxygen demand · Jaguari River - Atibaia River

\section{Introduction}

Water, essential to life, has been a concerning matter in the world, depending on its quantity and quality, and in some areas, conflicts are in evidence because of it. In addition to its irregular distribution, which limits development in several regions of the planet, the hydric stress is becoming a hazard in cities far from traditionally arid 
regions. With the volume and constant reuse, surface water, when available, requires prior sanitary treatment to be use for public supply. This fact is a consequence of the accumulation of harmful chemicals from disordered anthropogenic actions. The discharges of urban and industrial effluents, without proper treatment, are the major responsible for the deterioration of aquatic environments (Oliveira et al. 2012).

The Southeast of Brazil, located on the tropical region, has high population occupation, industry, and agriculture, with consequently increased use of its waters. In this region, where the rivers Jaguari and Atibaia are located, surface freshwater is becoming scarce.

The Atibaia River, located near the municipality of Paulínia, suffers great anthropogenic influence from several sources of contamination. Among these sources contributing to this pollution are: domestic effluents (many times untreated), chemical and cellulose industries, and an oil refinery. Moreover, this pollution may also be associated to urban and rural diffuse loads from agriculture, livestock, and mining, especially the exploitation and commercialization of sand. Each of these examples represents a kind of characteristic pollutant that is carried by water (Leite et al. 2013).

The Jaguari River Basin covers an extensive area occupied by agricultural and livestock activities. The basin is under greater influence of the diffuse pollution, which is generated by land use and features intense degradation of its riparian forest.

The volume of freshwater from the mentioned rivers depends mainly on the rainy and warm season, occurring from October to March. Days with heavy rainfall are common in this period, causing flood events. The remaining months of the year (April to September) comprise the dry season, with lower temperatures. Thus, the region has only two defined seasons: rainy/ warm and dry/cold.

However, researchers alert to the climate change phenomenon, typified by extreme, intense droughts, and poorly distributed rainfall that has caused serious imbalances on the Planet.

Obregón et al. (2014) evaluated the rainfall occurring in the Metropolitan region of São Paulo, SP, Brazil, approximately $100 \mathrm{~km}$ far away from the municipality of Paulínia. The authors compiled data from the Meteorological Station of São Paulo, SP obtained during the years 1973 to 1997 and concluded that pluviosity alterations have been occurring since 1950 and that more heavy rainfall has recently become more evident, damaging the region, which is not adequately prepared to stand these changes. In 1950, there were three events with heavy rainfall (over $50 \mathrm{~mm}$ ), while in the years 2000 to 2014 , these events have increased $2-5$ times.

Intermittent rainfall is the main cause of diffuse pollution of urban and rural origin. This pollution involving organic and inorganic matter is derived, in part, from solid residues, sediments, industries, automobiles, and animals.

During dry season, mineral nitrogen may accumulate in the soil, and at the onset of rainfall, high nutrient loads are dragged to the river (Skoulikidis and Amaxidis 2009). The main cause of diffuse pollution generated by anthropogenic action is the increase of organic and inorganic loads, generating sludge resulting from the conversion of native vegetation of the river basin in agricultural and urban areas (Amorim et al. 2006; Dodson and Lillies 2001). Moreover, in small proportion are the sitelevel disturbances, such as proximity to roads and highways (Nelson and Booth 2002), the distance to the forest cover (Houlahan and Findlay 2003), the deforestation of riparian forest (Lammert and Allan 1999; Meador and Goldstein 2003), as well as the impact related to recreational activities (Kashian and Burton 2000) that may have primordial effects on the biotic community in the absence of changes in basin-wide land uses. The characteristics of a hard problem and diffuse water pollution provide a clear example of such a challenge.

Changes in land use and land cover (LULC) have been recognized as stressors of aquatic ecosystems and drainage areas (Hamel et al. 2013; Bu et al. 2014). Some of the most relevant effects are the reduced biodiversity and the impacts on the quality and quantity of water (Bedford 1999; Teixeira et al. 2014).

Tropical rivers are subject to great variability in volume induced by the rain. The river waters are not stagnated, but are subject to unidirectional current and have variable flow, in addition to suffering the influence of drainage conditions (Chapman 1996).

In Brazil, the classification and environmental guidelines for the framework on surface water bodies and water quality standards, seeking to improve environmental conditions, are being constantly reviewed by resolution of the National Environment Council (CONAMA 357/2005).

Several authors have studied the water quality parameters generating important data that needs to be interpreted 
(Rodrigues 1998; Pesce and Wunderlin 2000; Strieder et al. 2006; Kannel, et al. 2007; De Rosemond et al. 2009; Zanini et al. 2010; Lumb et al. 2011; Pinto Filho et al. 2012; Moura et al. 2013; Mostafaei 2014; Sharma et al. 2014; Cayax et al. 2014; Salla and Ghosh 2014; Amé and Pesce 2015; Lobato et al. 2015.

Among the difficulties to analyze these data are the selection of which variables can be used as an indicator of water quality. This selection must clearly reflect the changes in the aquatic environment arising from its use and that is under the influence of climatic, geological, size, and shape of drainage basins (Toledo and Nicolella 2002).

In order to facilitate the analysis and management of the hydrographical basin, the National Sanitation Foundation (NSF-USA) created, in 1970, the Water Quality Index (WQI), aiming at summarizing the numeric variation of physical, chemical, and biological parameters to a total value of quality (Brown et al. 1972). The WQI is a valuable information tool for different segments of industry, agriculture, environmental managers, and the general public. The Oregon Department of Environmental Quality (DEQ) uses the WQI to assess and report water quality trends for its use to the regulatory offices and to the public (Cude 2001).

The WQI is calculated by means of the product of $n$ parameters $(q)$ related to its significance by a numeric coefficient $w$, being $\sum_{i} w_{i}=1$

$$
\mathrm{WQI}=\prod_{i=1}^{n} q_{i}^{w_{i}}
$$

When added to the formula, the values of each parameter generate numeric values, which allow the referential attribute of water classification, according to its preponderant value.

The WQI original developed by NFS was adapted to the Brazilian reality by CETESB. However, WQI may induce the evaluations with less acuity of parameters involving, for example, the human health. That is why it is important to analyze each of the parameters of the series of analysis of the WQI (Barros et al. 2012).

For the calculation of WQI, the CETESB (2010) considers the following parameters: Escherichia coli, hydrogen ion potential $(\mathrm{pH})$, biochemical oxygen de-

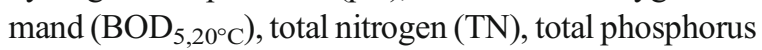
(TP), turbidity $(\mathrm{Tb})$, total solids (TS), and dissolved oxygen (DO). According to their importance in the general evaluation, each of these parameters receives a numeric coefficient $\left(\boldsymbol{w}_{\boldsymbol{i}}\right)$, which will be integrated to the final calculation of the WQI. Other countries also adopted the formulation of the WQI, adapting to their region. The several regulations differ in the importance of each parameter, according to Table 1.

The Brazilian Agency of Environment and Hydric Resources (CPRH 2013), based on the analysis of quality parameters, formulated indices for water monitoring applied to Brazilian lentic and lotic environments.

The WQI has been widely applied and accepted in European, African, and Asian countries (Singh et al. 2013). Sharma et al. (2014) reported the presence of 30 water quality indices, used in different regions, with a number of variables from 3 up to 72. The value of NSF ranges (WQI) from $(0-100)$ and the streams are classified as very bad, bad, medium, good, or excellent (Table 2).

The WQI, in its several weighing, allows to infer in the general water quality and. even if with a reasonable index, may present some parameter that does not contemplates the requirements for a save public supply water.

\section{Material and methods}

Characterization of the study area

The municipality of Paulínia has two main rivers, the Jaguari and Atibaia, and presents a Human Development Index (HDI) of 0.847 , according the United Nations

Table 1 Quality parameters and their respective numeric coefficients, according to several WQI's

\begin{tabular}{llll}
\hline Parameter $\left(q_{i}\right)$ & \multicolumn{2}{l}{ Numeric coefficient $\left(\boldsymbol{w}_{\boldsymbol{i}}\right)$} \\
\cline { 2 - 4 } & $\begin{array}{l}\text { Index León } \\
\text { México } \\
\text { (Dinius 1987) }\end{array}$ & $\begin{array}{l}\text { CETESB } \\
(2010)\end{array}$ & $\begin{array}{l}\text { NSF - USA } \\
\text { (Brown et al. } \\
1970)\end{array}$ \\
\hline E. coli. & - & 0.17 & 0.16 \\
BOD 5,20 C & 0.14 & 0.11 & 0.11 \\
Total nitrogen (TN) & 0.13 & 0.11 & 0.10 \\
Total phosphorus (TP) & - & 0.11 & 0.10 \\
Total solids (TS) & 0.10 & 0.09 & 0.07 \\
Turbidity (Tb) & 0.11 & 0.09 & 0.08 \\
Dissolved oxygen (DO) & 0.21 & 0.19 & 0.17 \\
Temperature (T) & - & - & 0.10 \\
pH & 0.14 & 0.13 & 0.11 \\
Non-toxic ionic & 0.17 & - & - \\
$\quad$ ammonia & & 1.0 & 1.0 \\
Sum of weights & 1.0 & & \\
\hline
\end{tabular}


Table 2 Score on WQIs with reference standards

\begin{tabular}{lllllll}
\hline Quality levels & $\begin{array}{l}\text { NSF - USA } \\
\text { (Brown et al. 1970) }\end{array}$ & $\begin{array}{l}\text { Oregon } \\
\text { (Dunnette 1979) }\end{array}$ & $\begin{array}{l}\text { León México } \\
\text { (Dinius 1987) }\end{array}$ & $\begin{array}{l}\text { British Columbia } \\
\text { (Ministry of } \\
\text { Environment, 1996) }\end{array}$ & CETESB (2010) & Alberta (CCME 2001) \\
\hline Excellent & $90 \leq 100$ & $90 \leq 100$ & $90 \leq 100$ & $60 \leq 100$ & $80 \leq 100$ & $96 \leq 100$ \\
Good & $70 \leq 89$ & $85 \leq 89$ & $70 \leq 89$ & $44 \leq 59$ & $52 \leq 79$ & $81 \leq 95$ \\
Medium & $50 \leq 69$ & $80 \leq 84$ & $50 \leq 69$ & $18 \leq 43$ & $37 \leq 51$ & $66 \leq 80$ \\
Bad & $25 \leq 49$ & $60 \leq 79$ & $25 \leq 49$ & $04 \leq 17$ & $20 \leq 36$ & $46 \leq 65$ \\
Very bad & $0 \leq 24$ & $\leq 60$ & $0 \leq 24$ & $0 \leq 03$ & $0 \leq 19$ & $0 \leq 45$ \\
\hline
\end{tabular}

Development Program, PIB of ca. U\$2000 and 26,000 per capita (IBGE 2010). The region presents tropical climate, annual precipitation of $1320.8 \mathrm{~mm}$, annual average of $110.07 \mathrm{~mm}$, with mean temperature variation of 16 to $30{ }^{\circ} \mathrm{C}$.

Besides, the region presents a biggest industrial pole of Latin America, with several chemical and petrochemical industries, and the biggest petroleum refinery concerning the production of processed petroleum.

The municipality of Paulínia is occupied $9 \%$ by perennial cultures, $29 \%$ by non-perennial cultures, $8 \%$ by pastures, $2 \%$ by natural vegetation, and $0.5 \%$ by reforestation (Leite et al. 2013). The most widespread culture is sugar cane, followed by orange, manioc, corn, and horticultural products.

\section{Sampling points location}

The sampling points in the rivers Jaguari and Atibaia were defined in the municipality of Paulínia, SP, Brazil since the water from upstream serves as public supply to several towns (Fig. 1).

Although the proximity among these rivers, they belong to different hydrographical basins, suffering different influences (Fig. 2). The sampling point 1, in the Jaguari River (P1), is located at $22^{\circ} 41^{\prime} 48.6^{\prime \prime}(\mathrm{S}) 47^{\circ} 07^{\prime} 21.1^{\prime \prime}(\mathrm{W})$ and the sampling point 2, in the Atibaia River (P2), is located at $22^{\circ}$

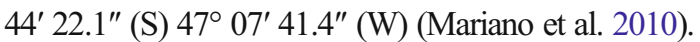

\section{Sampling period}

The sampling period comprised $<66$ months, beginning in October 2009 and ending in March 2015, totalizing 109 sampling campaigns, being 53 samples from rainy period and 56 from dry period. Depending on the climatic conditions, the sampling campaigns were performed in intervals of 15 or 25 days.
The sampling in the Jaguari and Atibaia rivers, performed in rainy and dry periods, and the number of collected samples, according to the temporal identification, are presented in Table 3.

Sampling procedures

Water sampling in the rivers composed of 10 sub-samples collected from the right edge to the left edge of each point (CETESB 1998). Polyethylene gallons of $10 \mathrm{~L}$ were used, and samples were preserved and processed according to APHA (2005). All the analyzed parameters were realized with replicates.

Analysis of water quality parameters

The samples were analyzed according to chemical, physical, and biological parameters, according to the Standard Methods APHA (2005), in the Laboratory of Teaching and Research in Water Toxicity, Institute of Biosciences, University of São Paulo State (UNESP), Campus Rio Claro, SP, Brazil.

The precipitation data $(\mathrm{mm})$ of the region were obtained from the Room of Telemetric Data Situation (RTDS) of the Hydrographical Basin Committee Agency of Piracicaba, Capivari and Jundiaí rivers (CBH-PCJ) and used to compare rainy and dry periods.

For the calculation of WQI of this study, the E. coli,

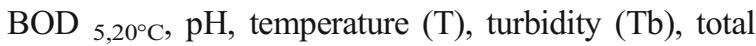
solids (TS), total nitrogen (TN), total phosphorus (TP), and dissolved oxygen (DO) were analyzed. The BOD and $E$. coli parameters were selected in this evaluation and correlated to the values of WQI.

Calculation of the Water Quality Index

The WQI calculations were performed applying the data of the chosen parameters in worksheets. These 


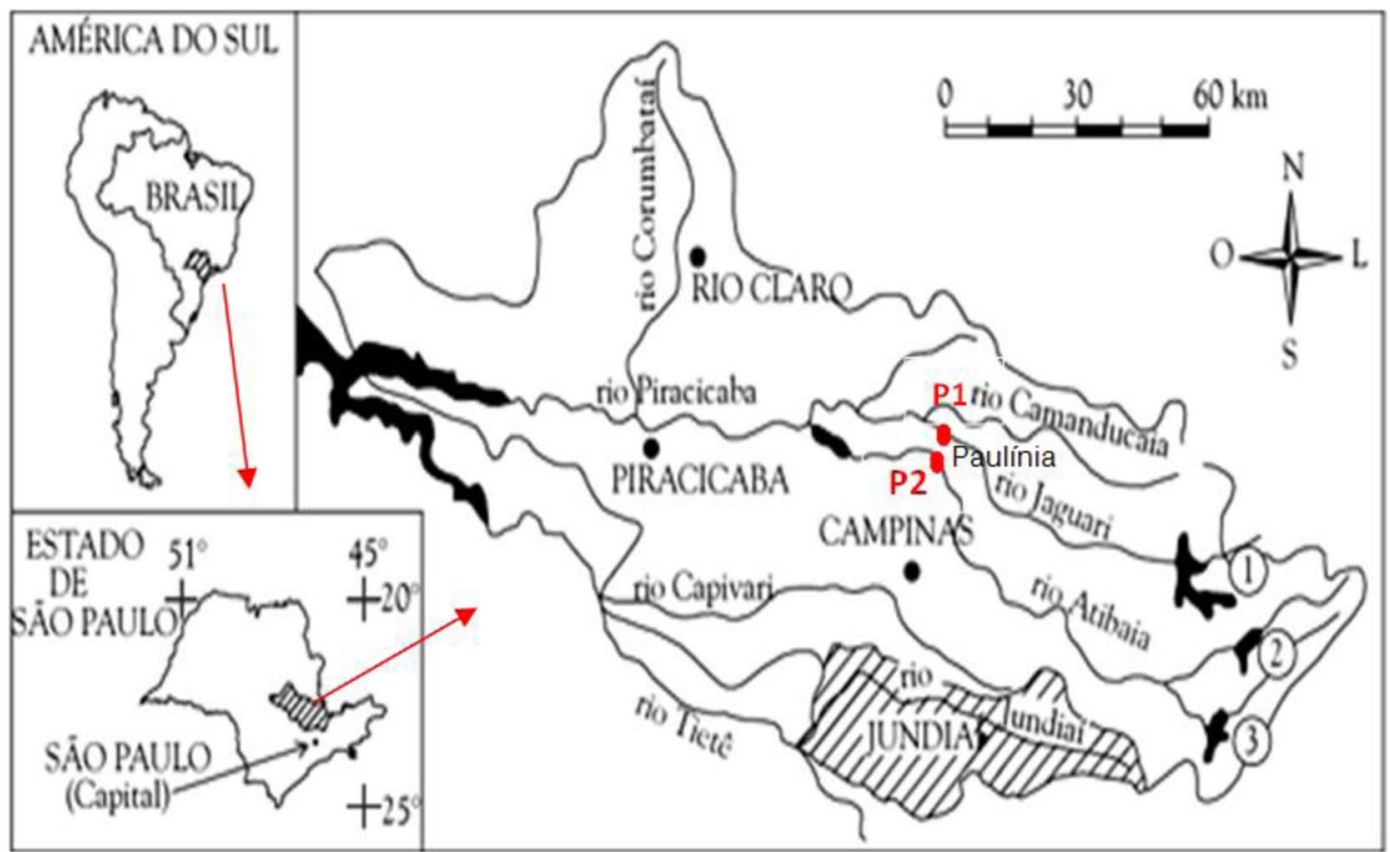

Fig. 1 Sampling points location and cartographical evidences of the extension of Atibaia and Jaguari rivers

worksheets belong to the Database Management System, called Water Quality Calculation System (WQCS) of the National Environmental Program (PNMA II 2005). The WQCS combines the calculated values of the WQI. Interpretation of the results followed the classification presented in Table 2.

\section{Statistical analysis}

Considering that there is no normality of the data, the statistical analysis was performed using techniques of "non-parametric statistics," which makes no assumptions about the distribution of data (Connover 1980; Hollander et al. 2013).

The statistical analysis to compare the average values between the two periods was performed using the nonparametric Kruskal Wallis method, considering $5 \%$ significance. In order to determine significant differences among the periods, for post hoc tests in pairs, when the Kruskal Wallis test results in some differences between groups, the Dunn test (Dunn 1964) with Holm correction was performed (Holm 1979).

\section{Results and discussion}

According to the Brazilian legislation (CONAMA $357 / 2005$ ), river waters containing until 1000 E. coli $\left(\mathrm{MPN} \times 10^{-2} \times \mathrm{mL}^{-1}\right), 5.0 \mathrm{mg} \mathrm{O} \mathrm{O}_{2} \times \mathrm{L}^{-1}$ of DBO are amenable to treatment for public supply. The CETESB (2010) classifies the waters according to the ranges of values determined by WQI as presented in Table 2.
Fig. 2 a Jaguari River: with clear water, dominance of agricultural activity influence; b Atibaia River: with muddy waters, under the influence of chemical, petrochemical, agricultural, and urban activities

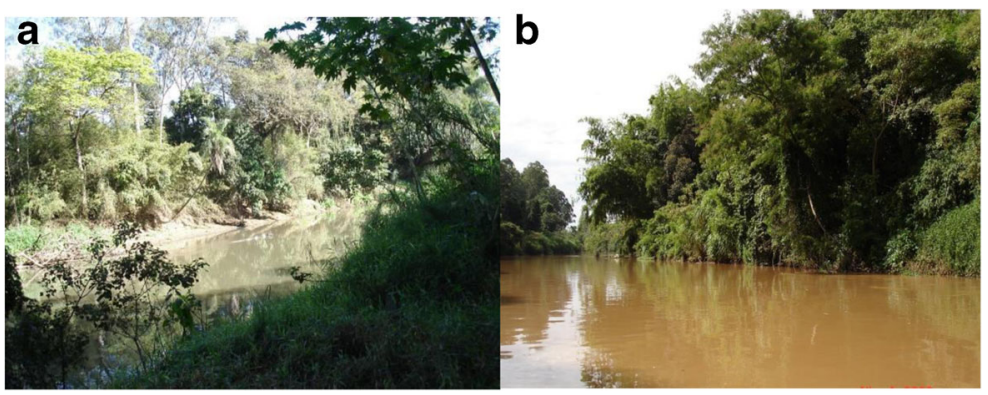


Table 3 Temporal characterization of sampling campaigns and number of samples collected in the rainy and dry periods

\begin{tabular}{llllll}
\hline Rainy season & Month/year & $\begin{array}{l}\text { Number of } \\
\text { samples }\end{array}$ & $\begin{array}{l}\text { Dry } \\
\text { season }\end{array}$ & Month/year & $\begin{array}{l}\text { Number of } \\
\text { samples }\end{array}$ \\
\hline SR1 & $10 / 2009$ to 03/2010 & 10 & SD1 & $04 / 2010$ to 09/2010 & 11 \\
SR2 & $10 / 2010$ to 03/2011 & 8 & SD2 & $04 / 2011$ to 09/2011 & 7 \\
SR3 & $10 / 2011$ to 03/2012 & 8 & SD3 & $04 / 2012$ to 09/2012 & 13 \\
SR4 & $10 / 2012$ to 03/2013 & 9 & SD4 & $04 / 2013$ to 09/2013 & 13 \\
SR5 & $10 / 2013$ to 03/2014 & 9 & SD5 & $04 / 2014$ to 09/2014 & 12 \\
SR6 & $10 / 2014$ to 03/2015 & 9 & & & \\
\hline
\end{tabular}

Evaluation of rainy periods

The monitoring data revealed that, in the sampling campaign performed in 2009, in rainy period (SR1), higher valued $E$. coli $\left(\mathrm{MPN} \times 10^{-2} \times \mathrm{mL}^{-1}\right)$ were registered, in both rivers, and Atibaia River (49.5) presented the higher contamination in comparison to Jaguari River (22.5).

Between the years 2009 and 2015, from 109 collected samples, in the rainy and dry seasons, the percentages of $E$. coli in disagreement with the legislation in the Jaguari River were respectively of 64.1 and $46.4 \%$, while in Atibaia River was of 75.5 and $66.1 \%$.

Abrupt changes in the BOD values in Atibaia River were recorded. These variations are due to other specific pollution sources, which were not originating from diffuse pollution carried out by rain. The water of the Atibaia River crosses areas densely populated and of intense anthropogenic activities, receiving high pollutant loads of organic and inorganic matter reflected in BOD values. It was possible to verify that, for the parameter BOD, $95 \%$ of the samples collected in rainy period presented values in disagreement with the legislation.

In the rainy period of 2009 (SR1), the highest average rainfall $(214 \mathrm{~mm})$ was recorded, presenting a WQI of 41.0 (regular) to the Jaguari River and of 34.0 (bad) to Rio Atibaia. In the period SR1, from 10 sampling performed in the Jaguari and Atibaia rivers, for the E. coli $8 / 10$ and $10 / 10$ and for DBO 6/10 and 8/10 were in disagreement to the Brazilian legislation CONAMA 357 (2005). In the period SR6 for both rivers, the DBO was in disagreement to the Brazilian legislation and in the periods SR1 to SR6, the values (\%) of WQI were of 30.2 and $60.4 \%$ in Jaguari and Atibaia rivers, respectively. In these periods, all analyzed samples were in disagreement to the Brazilian legislation for the DBO (Table 4).

Regarding the WQI, Jaguari River is considered, most of the time, presenting regular quality. However, the values of $E$. coli do not comply the requirements of the environmental control agency. Spearling (2005) emphasizes that the original purpose of the WIQ was to communicate the environmental managers and the interested public about the conditions of environmental quality. However, the parameter $E$. coli evaluated in 109 sampling campaigns demonstrate that the WQI often does not reflect the sanitary quality of the waters. Due to deficiency of riparian vegetation, Jaguari River, especially in sectors of intensive agricultural and livestock activity, presents lower WQI values. This effect is explained by the presence of diffuse sources of pollution (organic and mineral sources used in soil fertilization) carried by rain.

According to the Kruskal Wallis test, with the WQI as the dependent variable, it is possible to verify that there are significant differences between the rainy periods, only for Atibaia River $(p=0.001)$, and these differences are not recorded for Jaguari River. Using the post hoc Dunn's test, it is possible to register that the statically significance of $5 \%$ occurs in the period SR6, in relation to the periods SR2 and SR4. The period SR6 presents mean and median values of WQI considerably lower when compared to the others, as presented in Fig. 3 (obs: the symbol+represents the average of the values).

Regarding E. coli, there is a significant difference $(p=0.0005)$ only for Atibaia River, in rainy periods. This difference occurs when comparing the period SR3 to the periods SR1 and SR2 once the period SR3 presents the lowest mean value of $E$. coli, as presented in Fig. 4.

Related to the BOD values, there are significant differences only in rainy periods in the Jaguari River $(p=0.0367)$. The results obtained by Dunn's test indicated that the differences in Jaguari River occurred most significantly among the periods SR4 and SR6 $(p=0.005)$. In Fig. 5, it is possible to observe that the mean values of period SR6 were higher if compared to the mean values of period SR4. 
Table 4 WQI analysis in the rainy period for Jaguari and Atibaia rivers, related to E. coli $\left.\left(\mathrm{MPN} \times 10^{-2} \times \mathrm{mL}^{-1}\right), \mathrm{BOD}_{(\mathrm{mg} \mathrm{O}} \times \mathrm{L}^{-1}\right), \mathrm{mean}^{-}$ of precipitation $(\mathrm{mm})$, and number of samples in disagreement with the Brazilian legislation

\begin{tabular}{|c|c|c|c|c|c|c|c|c|}
\hline \multirow[t]{2}{*}{ Season rainy } & \multirow[t]{2}{*}{ Parameters } & \multicolumn{3}{|c|}{ Jaguari river } & \multicolumn{3}{|c|}{ Atibaia river } & \multirow[t]{2}{*}{ Precipitation } \\
\hline & & WQI & E. coli $\times 10^{3}$ & DBO & WQI & E. coli $\times 10^{3}$ & DBO & \\
\hline \multirow[t]{3}{*}{ SR1 } & Mean & 41.0 & 22.5 & 8.2 & 34.0 & 49.5 & 11.8 & 214.0 \\
\hline & Standard deviation & 6.3 & 49.8 & 5.8 & 4.0 & 96.2 & 3.5 & 120.0 \\
\hline & Disagree & $1 / 10$ & $8 / 10$ & $6 / 10$ & $8 / 10$ & $10 / 10$ & $8 / 10$ & - \\
\hline \multirow[t]{3}{*}{ SR2 } & Mean & 43.0 & 11.0 & 9.5 & 38.0 & 9.7 & 20.0 & 181.0 \\
\hline & Standard deviation & 7.2 & 18.7 & 4.7 & 6.0 & 10.8 & 17.0 & 174.0 \\
\hline & Disagree & $4 / 8$ & $4 / 8$ & $7 / 8$ & $5 / 8$ & $7 / 8$ & $8 / 8$ & - \\
\hline \multirow[t]{3}{*}{ SR3 } & Mean & 39.4 & 7.3 & 13.2 & 41.0 & 1.0 & 13.0 & 153.0 \\
\hline & Standard deviation & 3.8 & 9.2 & 7.3 & 5.0 & 0.3 & 5.0 & 57.0 \\
\hline & Disagree & $3 / 8$ & $8 / 8$ & $7 / 8$ & $1 / 8$ & $2 / 8$ & $8 / 8$ & - \\
\hline \multirow[t]{3}{*}{ SR4 } & Mean & 44.6 & 1.9 & 6.3 & 42.0 & 2.9 & 9.0 & 145.0 \\
\hline & Standard deviation & 6.1 & 1.1 & 5.0 & 4.0 & 1.5 & 7.0 & 72.0 \\
\hline & Disagree & $0 / 9$ & $3 / 9$ & $5 / 9$ & $3 / 9$ & $7 / 9$ & $7 / 9$ & - \\
\hline \multirow[t]{3}{*}{ SR5 } & Mean & 43.4 & 1.1 & 10.6 & 34.0 & 2.1 & 12.0 & 44.5 \\
\hline & Standard deviation & 3.4 & 0.6 & 4.1 & 5.0 & 0.7 & 3.0 & 34.2 \\
\hline & Disagree & $1 / 9$ & $5 / 9$ & $9 / 9$ & $9 / 9$ & $9 / 9$ & $9 / 9$ & - \\
\hline \multirow[t]{4}{*}{ SR1 to SR5 } & Mean 2009/2010 & 42.3 & 8.8 & 9.6 & 37.8 & 13.0 & 13.2 & 147.5 \\
\hline & Standard deviation & 2.8 & 21.4 & 1.2 & 6.0 & 0.2 & 4.0 & 58.1 \\
\hline & Disagree & $13 / 44$ & $28 / 44$ & $34 / 44$ & $26 / 44$ & $35 / 44$ & $40 / 44$ & \\
\hline & Disagree (\%) & 24.5 & 50.9 & 64.2 & 49.1 & 66.0 & 75.5 & \\
\hline \multirow[t]{3}{*}{ SR6 } & Mean & 41.7 & 3.6 & 15.0 & 31.0 & 3.5 & 19.0 & 134.0 \\
\hline & Standard deviation & 7.6 & 2.9 & 3.0 & 3.0 & 3.0 & 7.0 & 109.0 \\
\hline & Disagree & $3 / 9$ & $6 / 9$ & $9 / 9$ & $6 / 9$ & $5 / 9$ & $9 / 9$ & - \\
\hline \multirow[t]{2}{*}{ SR1 to SR6 } & Total mean & 42.2 & 7.9 & 10.5 & 36.7 & 11.5 & 14.1 & 145.3 \\
\hline & Disagree (\%) & 30.2 & 64.1 & 81.1 & 60.4 & 75.5 & 92.5 & \\
\hline
\end{tabular}

\section{Evaluation of dry periods}

In the dry periods, SD1 to SD5, E. coli decrease in the Jaguari River to $50 \%$ in relation to the rainy periods SR1 to SR2, which are in accordance to Oliveira and Cunha (2014).

In the dry periods, SD1 to SD5, E. coli decreased in Jaguari river to $50 \%$ in relation to the rainy periods SR 1 to SR2, which are in accordance to Oliveira and Cunha (2014), who stated that, during the rainy season, there is an increase of bacteria. Those authors found out that the increase in the pluviosity may interfere in the sanitary conditions, independently on the punctual or diffuse pollution.

The study verified that the increased precipitation interferes in the sanitary conditions, independently of the point or diffuse pollution. For the parameter E. coli, the statistically significant difference occurred in Jaguari River, in the dry period $(p=0.048)$. The application of the Dunn's test highlighted the difference among the periods SD3 and SD5 $(p=0.047)$.

The statistical confidence level of $95 \%$ revealed that the period SD3 presented quantitative values of $E$. coli, higher than the period SD5. The decreasing concentration of $E$. coli highlighted a slight sanitary improvement, in the WQI in Jaguari River waters (Table 5).

The data presented in Table 5 indicate that, in the dry season, the region covered by the rivers Jaguari and Atibaia had low rainfall $(60.8 \mathrm{~mm})$ and other factors, which are not considered in this study, may influence the evaluation of the WQI.

The mean values of periods SR1 to SR5, with mean values of precipitation of $143.5 \mathrm{~mm}$, correspond to the warmer season and coincide with the most intense 
Fig. 3 Boxplot of WQI values by rainy periods in the Atibaia River

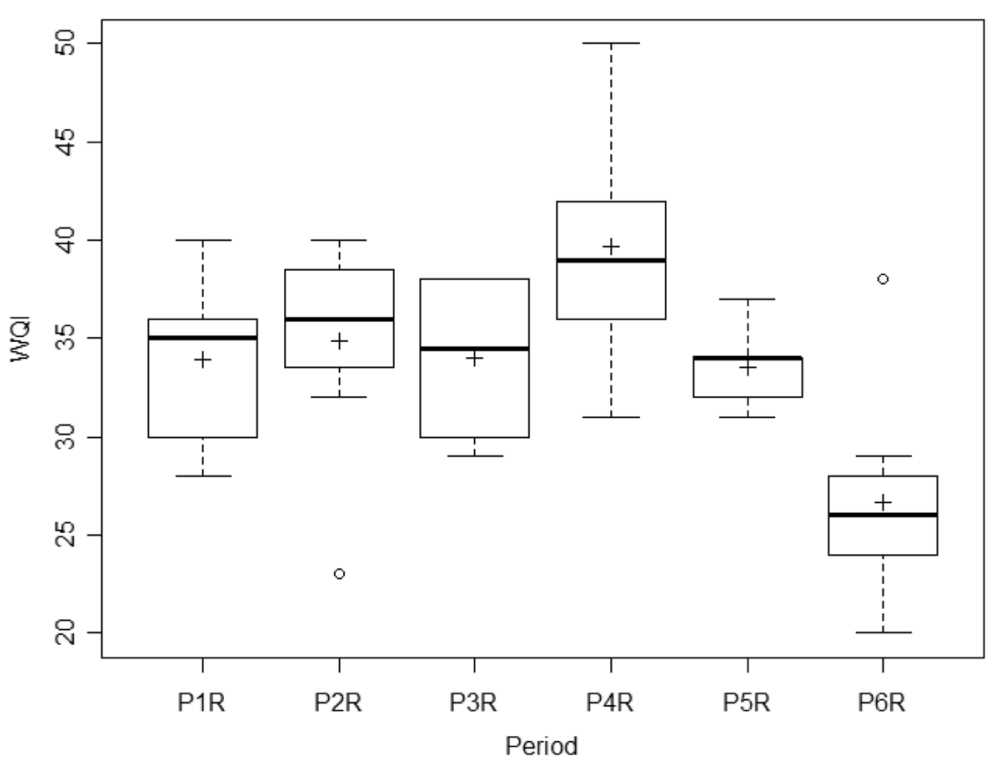

precipitations. From 2010 to 2013, a decreasing precipitation average was recorded, making the precipitation in 2014 an atypically dry period, with high hydric scarcity, comparable to the mean values obtained in the dry period (44.5 and $44.0 \mathrm{~mm}$ ), respectively.

The mean values of precipitation in the dry periods of 2009 and 2013 slightly increased. However, in 2014, these values significantly decreased, culminating in a severe drought ravaging the studied region, as presented in Fig. 6, which presents the mean values of precipitation and temperatures. The data obtained for Jaguari and Atibaia rivers are related to same variables due to the geographical proximity of those rivers.
The WQI presents significant differences among the dry periods $(p=0.015)$ only for Atibaia River, with no differences for the Jaguari River. These differences, in Atibaia River, occur between the periods SD3 and SD1 and also between the periods SD3 and SD5. Figure 7 records the periods SD5 and SD1 presented the higher values of WQI, in comparison to the period SD3, which had the lowest median between the periods studied.

The parameter BOD presented statistically significant differences among the dry periods in the Jaguari River $(p=0.0455)$. According to Dunn's test, the major difference occurred between the periods SD1 and SD3 $(p=0.02)$ and there is also a
Fig. 4 Boxplots of E. coli by rainy periods in the Atibaia River

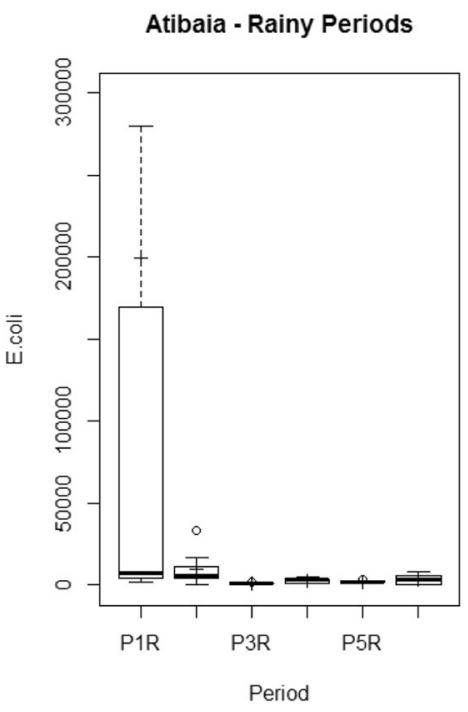

Atibaia - Rainy Periods (y-bar limited)

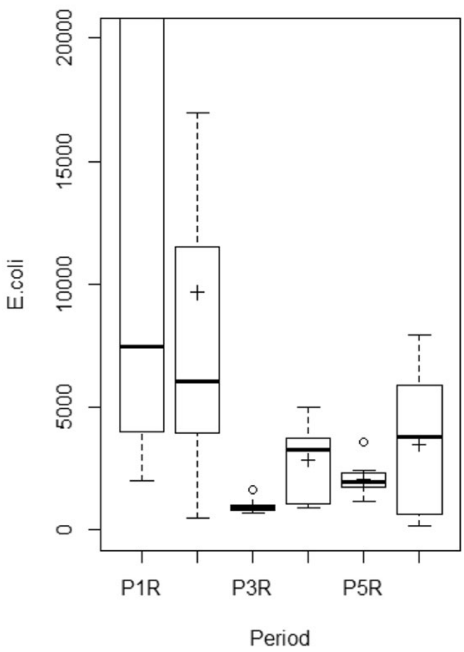


Fig. 5 Boxplot of BOD by rainy periods in the Jaguari River

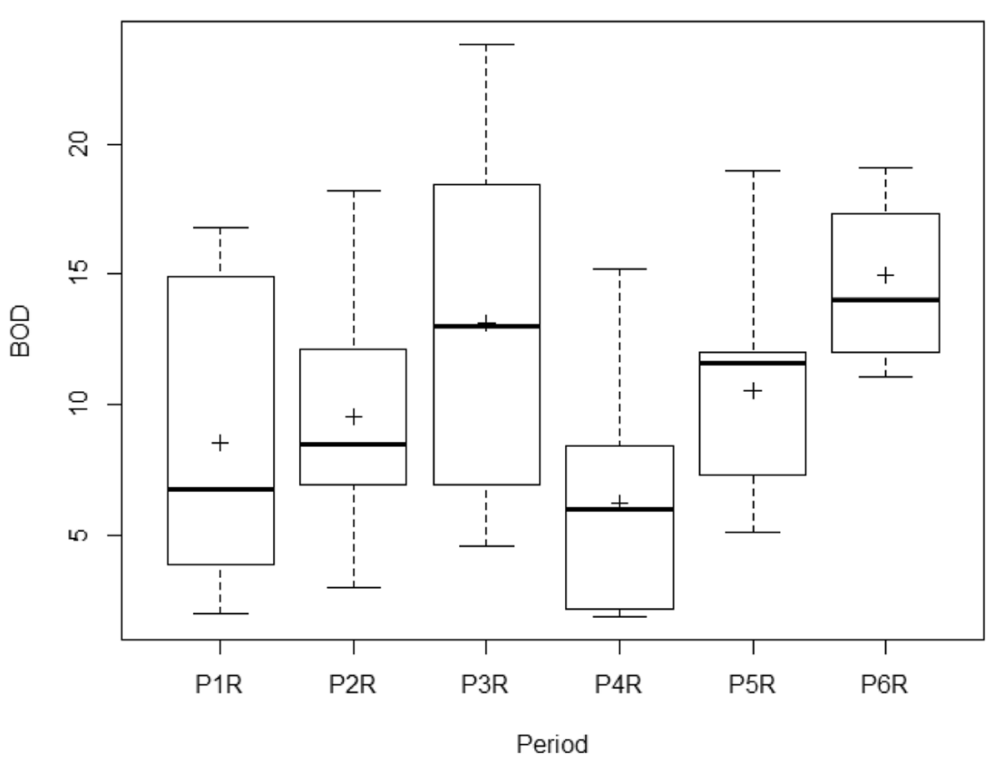

difference between periods SD1 and SD4 $(p=0.04)$. In Fig. 8, it is possible to observe that the mean values of BOD for the periods SD3 and SD4 were higher when compared to the others. For Atibaia

Table 5 WQI analysis in the dry period for Jaguari and Atibaia rivers, related to $E$. coli $\left(\mathrm{MPN} \times 10^{-2} \times \mathrm{mL}^{-1}\right), \mathrm{BOD}\left(\mathrm{mg} \mathrm{O}_{2} \times \mathrm{L}^{-1}\right)$, $\mathrm{mean}$ of precipitation $(\mathrm{mm})$, and number of samples in disagreement with the Brazilian legislation

\begin{tabular}{|c|c|c|c|c|c|c|c|c|}
\hline \multirow[t]{2}{*}{ Season Dry } & \multirow[t]{2}{*}{ Parameters } & \multicolumn{3}{|c|}{ Jaguari River } & \multicolumn{3}{|c|}{ Atibaia River } & \multirow[t]{2}{*}{ Precipitation } \\
\hline & & WQI & E. coli $\times 10^{3}$ & DBO & WQI & E. coli $\times 10^{3}$ & DBO & \\
\hline \multirow[t]{3}{*}{ SD1 } & Mean & 44.3 & 2.5 & 7.0 & 39.1 & 12.8 & 12 & 40.0 \\
\hline & Standard deviation & 4.8 & 3.6 & 3.0 & 5.0 & 15.5 & 4.0 & 24.0 \\
\hline & Disagree & $0 / 11$ & $5 / 11$ & $10 / 11$ & $6 / 11$ & $8 / 11$ & $10 / 11$ & \\
\hline \multirow[t]{3}{*}{$\mathrm{SD} 2$} & Mean & 35.3 & 2.8 & 7.0 & 31.9 & 23.1 & 14.3 & 49.0 \\
\hline & Standard deviation & 5.5 & 2.0 & 3.0 & 4.9 & 21.1 & 6.9 & 44.0 \\
\hline & Disagree & $3 / 7$ & $5 / 7$ & $6 / 7$ & $5 / 7$ & $7 / 7$ & $7 / 7$ & \\
\hline \multirow[t]{3}{*}{ SD3 } & Mean & 41.0 & 7.5 & 14.0 & 38.1 & 5.3 & 12.6 & 72.0 \\
\hline & Standard deviation & 7.9 & 11.0 & 9.0 & 6.0 & 8.6 & 4.3 & 84.0 \\
\hline & Disagree & $6 / 13$ & $9 / 13$ & $12 / 13$ & $5 / 13$ & $6 / 13$ & $13 / 13$ & \\
\hline \multirow[t]{3}{*}{ SD4 } & Mean & 40.0 & 1.3 & 13 & 37.5 & 10.2 & 11.8 & 99.0 \\
\hline & Standard deviation & 5.8 & 1.1 & 8.0 & 4.7 & $12 . .2$ & 5.4 & 72.0 \\
\hline & Disagree & $0 / 13$ & $7 / 13$ & $12 / 13$ & $10 / 13$ & $13 / 13$ & $12 / 13$ & \\
\hline \multirow[t]{3}{*}{$\mathrm{SD} 1$ to SD4 } & Mean & 40.2 & 4.0 & 10.3 & 36.7 & 12.8 & 12.7 & 65.0 \\
\hline & Disagree & $9 / 44$ & $26 / 44$ & $40 / 44$ & $27 / 44$ & $34 / 44$ & $42 / 44$ & \\
\hline & Disagree (\%) & 20.5 & 59.1 & 90.6 & 48.1 & 70.3 & 95.5 & \\
\hline \multirow[t]{3}{*}{ SD5 } & Mean & 39.9 & 0.3 & 10.0 & 27.9 & 5.4 & 17.4 & 44.0 \\
\hline & Standard deviation & 10.9 & 0.2 & 4.0 & 6.3 & 7.8 & 5.9 & 49.0 \\
\hline & Disagree & $2 / 12$ & $0 / 12$ & $10 / 12$ & $10 / 12$ & $8 / 12$ & $10 / 12$ & - \\
\hline \multirow[t]{2}{*}{ SD1 to SD5 } & Total mean & 40.1 & 2.9 & 10.2 & 34.9 & 11.4 & 13.6 & 60.8 \\
\hline & Disagree $(\%)$ & 19.6 & 46.4 & 89.3 & 49.8 & 66.1 & 92.9 & - \\
\hline
\end{tabular}


Fig. 6 Mean values of precipitation and temperature, for Jaguari and Atibaia rivers, from 2010 to 2015
Precipitation mean $(\mathrm{mm})$

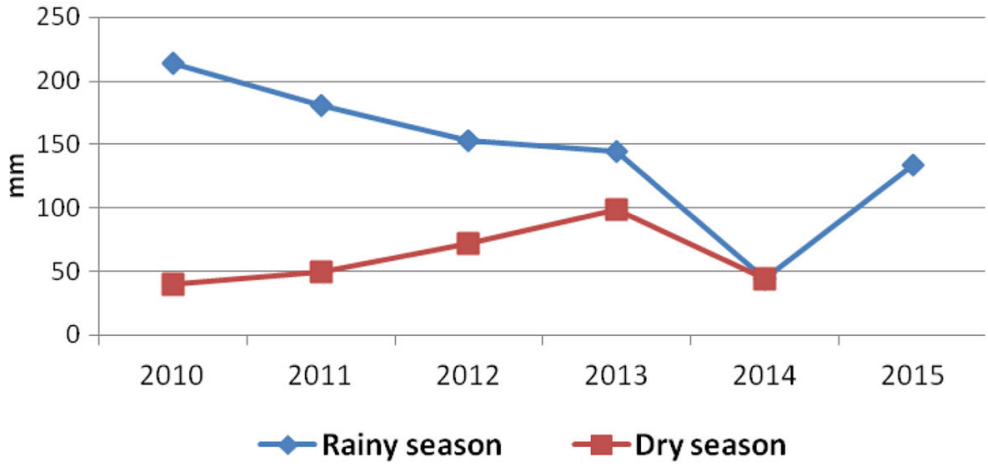

Temperature mean $(\mathrm{OC})$

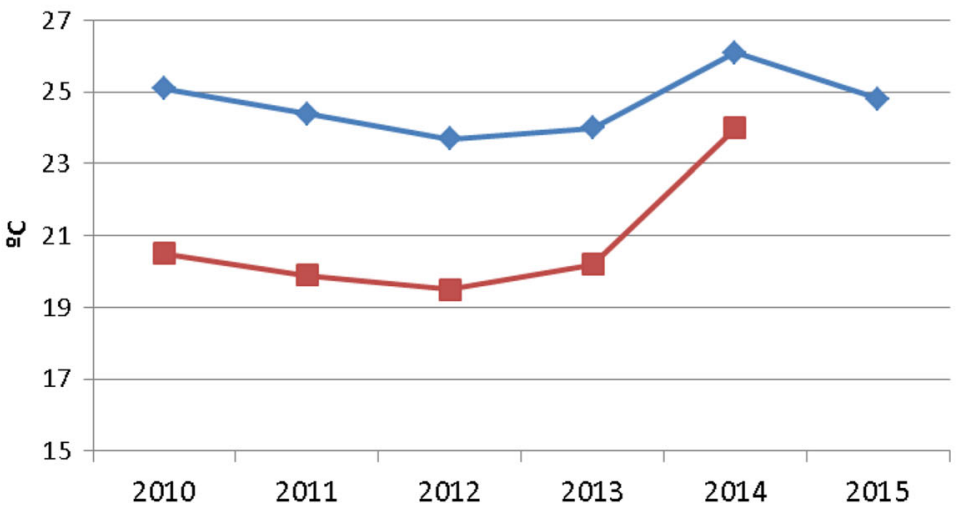

River, there were no statistically significant differences for the parameter BOD between the periods SD1 and SD5, with $5 \%$ significance.
The parameter $E$. coli presented significant difference for both Jaguari River $(p=0.0009)$ and Atibaia River $(p=0.0146)$. In the Jaguari River,
Fig. 7 Boxplot of the WQI by dry periods in Atibaia River

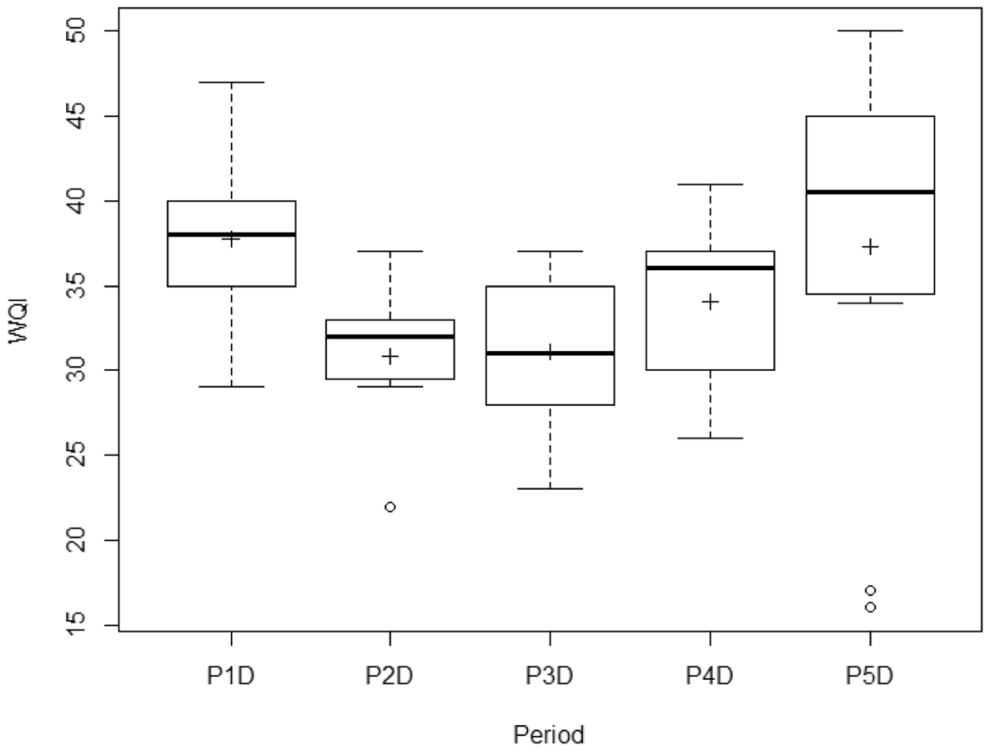


Fig. 8 Boxplot of BOD by dry periods in Jaguari River

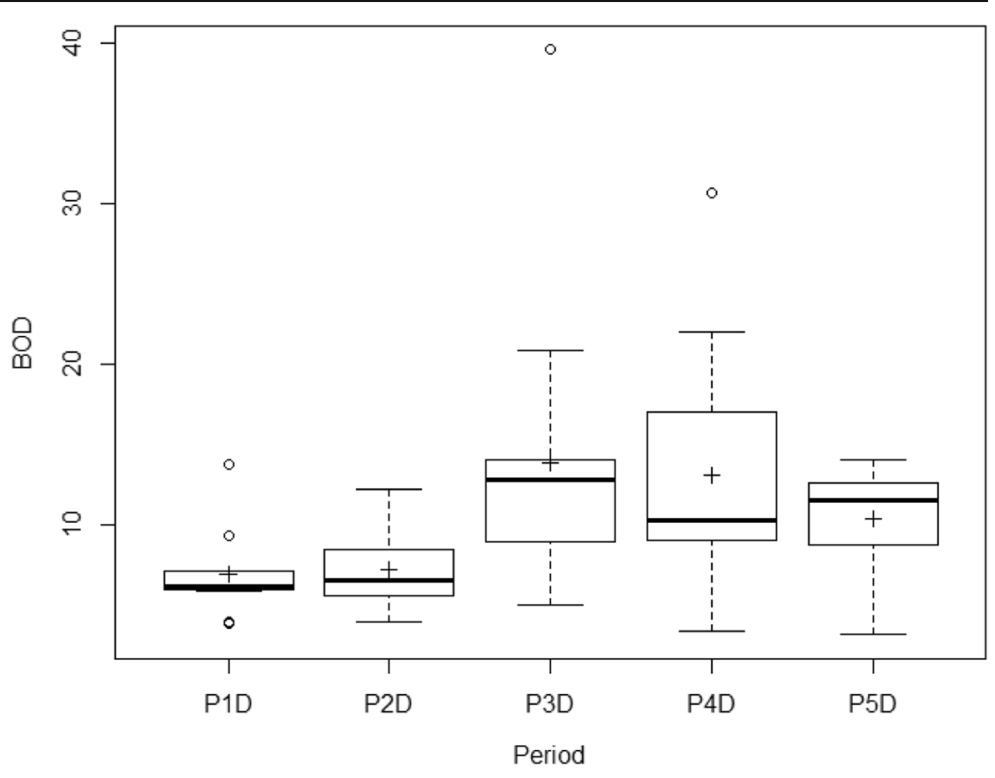

the differences occurred among the period SD5 and the periods SD1, SD2, and SD3. In the Atibaia River, the difference occurred among the periods SD2 and SD3. In Fig. 9, it is possible to observe that, for Jaguari River, period SD5 recorded lower value of $E$. coli when compared to the other periods (especially the periods SD1 to SD3), while, for Atibaia River, the lower value was recorded in the period SD3 and the highest in the period SD2.
Classification of average levels of water quality

Values of the parameters E. coli and BOD that exceeded the limits established by environmental legislation, in most of the samplings, negatively adversely affected the water quality of the Atibaia and Jaguari rivers. The analytical data obtained in this research demonstrate the need for immediate administrative measures of water management for sustainable use of these rivers in the study area. Table 6 presents the scores and classification of the average levels
Fig. 9 Boxplots of E. coli by dry periods for Atibaia and Jaguari rivers

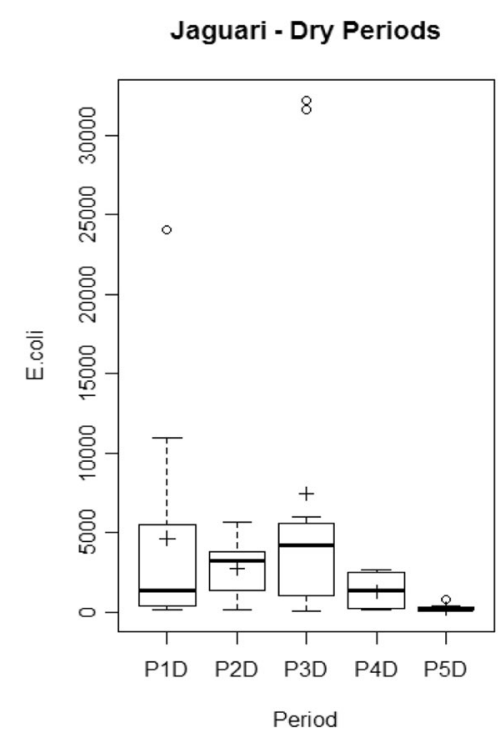

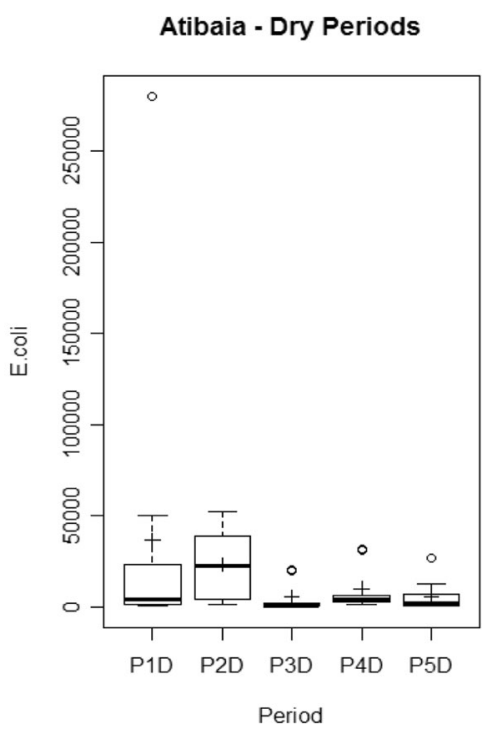


Table 6 Classification of the average levels of water quality of the rivers Jaguari and Atibaia, from October 2009 to March 2014

\begin{tabular}{|c|c|c|c|c|}
\hline \multirow[t]{2}{*}{ Season } & \multicolumn{2}{|c|}{ Jaguari River } & \multicolumn{2}{|c|}{ Atibaia River } \\
\hline & WQI & Classification & WQI & Classification \\
\hline SR1 & 43.0 & Medium & 33.8 & Bad \\
\hline SR2 & 39.4 & Medium & 34.8 & Bad \\
\hline SR3 & 35.3 & $\mathrm{Bad}$ & 33.9 & $\mathrm{Bad}$ \\
\hline SR4 & 41.0 & Medium & 39.7 & Medium \\
\hline SR5 & 40.0 & Medium & 33.5 & Bad \\
\hline SR6 & 39.9 & Medium & 26.7 & Bad \\
\hline SD1 & 44.3 & Medium & 39.1 & Medium \\
\hline SD2 & 35.3 & $\mathrm{Bad}$ & 31.9 & $\mathrm{Bad}$ \\
\hline SD3 & 41.0 & Medium & 38.1 & Medium \\
\hline SD4 & 40.0 & Medium & 37.5 & Medium \\
\hline SD5 & 39.9 & Medium & 27.9 & $\mathrm{Bad}$ \\
\hline Mean & 39.19 & Medium & 34.26 & $\mathrm{Bad}$ \\
\hline Standard Deviation & 2.7 & & 4.3 & \\
\hline
\end{tabular}

of water quality of the rivers Jaguari and Atibaia, from October 2009 to March 2014, in rainy (SR1 to SR6) and dry (SD1 to SD6) periods, according to CETESB (2010).

The rivers Jaguari and Atibaia presented average levels from regular to bad quality from October 2009 to March 2015. The Jaguari River presented two bad classifications. The Atibaia River presented five bad classifications in the rainy period and two bad during the dry period. The WQI indications of regular for both rivers are numerically very close to the bad WQI.

The results presented in Table 6 indicate that the Jaguari River has more stability related to its quality $(\mathrm{SD}=2.7)$ than Atibaia River, which is more venerable in rainy period.

In addition, by examining a detailed description of the sub-indices of E. coli and BOD in the rivers, it was possible to observe that, for some periods, the rivers presented alarming values in relation to the sanitary quality of their water. This research verified the need of a better environmental management, as can be observed in the standard deviations presented in Table 6, considering that the hydrographical basin of both rivers supply a population of more than five million inhabitants, which may have health issues due to the water quality of these rivers.

Final considerations

Considering the WQI classification, according to the Canadian and Mexican models, the Brazilian environmental councils, associated with the hydric quality councils, must continue to intensively invest in the quality control of the WQI, considering E. coli as reference, monitoring the waste water treatment and the diffuse pollution. The diffusion pollution may be minimized by the intense reforestation of riparian forests and environmental education concerning the water.

Classification levels of Brazilian WQI (CETESB) are considerably different from most countries standards. Because of this, the classifications based in Brazilian WQI are sometimes fragile and overestimate the water quality, instead of revealing possible problems.

It is possible to conclude that analysis based only in the nine parameters for the WQI calculation are not sufficient to ensure the sanitary adequacy of the water body for its use determined by the environmental agency.

\section{References}

Amé, M. V., \& Pesce, S. F. (2015). Spatial and temporal changes in water quality along the basin. In The handbook of environmental chemistry (pp. 1-19). Berlin Heidelberg: Springer.

Amorim, J. M., Arruda, L. B., \& Pereira, H. J. (2006). Poluição difusa. Educação Ambiental em Ação, 28, 1-4.

APHA. (2005). Standard methods of examination of water and wastewater (20th ed.). Washington: American Public Health Association.

Barros, F. M., Martinez, M. A., Matos, A. T., \& Moreira, D. A. (2012). Distribuição quantitativa de qualidade de água coletada em diferentes pontos de um perfil transversal do rio turvo sujo, MG. Engenharia na Agricultura, Viçosa - Mg, 20(1).

Bedford, B. L. (1999). Cumulative effects on wetland landscapes: links to wetland restoration in the United States and southern Canada. Wetlands, 19(4), 775-788.

Brown, R. M., McClelland, N. I., Deininger, R. A., \& Tozer, R. G. (1970). A Water Quality Index-Do We Dare. Water Sewage Works, 117, 339-343.

Brown, R. M., McClelland, N. I., Deininger, R. A., \& O'Connor, M. F. (1972). A water quality index - crashing the psychological barrier. In Indicators of environmental quality (pp. 173-182). US: Springer.

Bu, H., Meng, W., Zhang, Y., \& Wan, J. (2014). Relationships between land use patterns and water quality in the Taizi River basin, China. Ecological Indicators, 41, 187-197.

Cayax, M. A. M., Chacon, E. A. V., \& Alvarez, N. G. (2014). Uso de la tierra y calidad del água superficial em lacuenca periurbana rio Platanitos, Guatemala. Revista Ingeniería Agrícola, 4(4), 19-23.

Canadian Council of Ministers of the Environment. (2001) Guidelines. http:/www.ccme.ca/initiatives/standards.html. Accessed 27 January 2015. 
CETESB, (1998). Companhia de Tecnologia de Saneamento Ambiental. Guia de coleta e preservação de amostras de água. São Paulo, 150.

CETESB. Companhia de Tecnologia de Saneamento Ambiental. (2010). Relatório de qualidade de águas superficiais do Estado de São Paulo 2009. São Paulo, p 310.

Chapman, D. (1996). Water quality assessments - A guide to use of biota, sediments and water in environmental monitoring (2ath ed.). London: E \& FN Spen - Chapman \& Hall.

CONAMA 357 (2005). Conselho Nacional do Meio Ambiente Resolução, p 23.

Connover, W. J. (1980). Practical nonparametrics statistics. New York: Wiley.

CPRH Agência Estadual de Meio Ambiente e Recursos Hídricos. (2013). Seleção de indices indicadores de qualidade de água. Aplicação dos índices selecionados. Recife: Oficina Nacional do Meio Ambiente.

Cude, C.G. (2001). Oregon water quality index a tool for evaluating water quality management effectiveness. 1:125-137.

De Rosemond, S., Duro, D. C., \& Dubé, M. (2009). Comparative analysis of regional water quality in Canada using the water quality index. Environmental Monitoring and Assessment, 156(1-4), 223-240.

Dinius, S. H. (1987). Design of water quality index. Water Resour Bull, Am Water Resour Assoc, 23(5), 823-843.

Dodson, S. I., \& Lillie, R. A. (2001). Zooplankton communities of restored depressional wetlands in Wisconsin, USA. Wetlands, 21(2), 292-300.

Dunn, O. J. (1964). Multiple comparisions using rank sums. Technometrics, 6, 241-252.

Dunnette, D. A. (1979). A geographically variable water quality index used in Oregon. Journal (Water Pollution Control Federation), 53-61.

Hamel, P., Daly, E., \& Fletcher, T. D. (2013). Source-control stormwater management for mitigating the impacts of urbanisation on baseflow: A review. Journal of Hydrology, 485, 201-211.

Hollander, M., Wolfe, D. A., \& Chicken, E. (2013). Nonparametric statistical methods. New York: Wiley.

Holm, S. (1979). A simple sequentially rejective multiple test procedure. Scandinavian Journal of Statistics, 6(2), 65-70.

Houlahan, J. E., \& Findlay, C. S. (2003). The effects of adjacent land use on wetland amphibian species richness and community composition. Canadian Journal of Fisheries and Aquatic Sciences, 60(9), 1078-1094.

Instituto Brasileiro de Geografia e Estatística. (2010). Available in: http://cidades.ibge.gov.br/painel/historico.php?lang= \&codmun=353650\&search=sao-paulo|Paulínia|infograficos:historico. Accessed 27 Jan 2015.

Kannel, P. R., Lee, S., Lee, Y. S., Kanel, S. R., \& Khan, S. P. (2007). Application of water quality indices and dissolved oxygen as indicators for river water classification and urban impact assessment. Environmental Monitoring and Assessment, 132(1-3), 93-110.

Kashian, D. R., \& Burton, T. M. (2000). A comparison of macroinvertebrates of two Great Lakes coastal wetlands: testing potential metrics for an index of ecological integrity. Journal of Great Lakes Research, 26(4), 460-481.

Lammert, M., \& Allan, J. D. (1999). Assessing biotic integrity of streams: effects of scale in measuring the influence of land use/cover and habitat structure on fish and macroinvertebrates. Environmental Management, 23(2), 257-270.

Leite, D. A. O., Ramos, M. A. G., Godoi, D. R., Mariano, A. P., Pião, A. C. S., \& Franceschi, D. A. (2013). Avaliação dos parâmetros do Î́ndice de Qualidade da Água segundo modelo estatístico ARIMA. Holos Environment, 13(1), 24-39.

Lobato, T. C., Hauser-Davis, R. A., Oliveira, T. F., Silveira, A. M., Silva, H. A. N., Tavares, M. R. M., \& Saraiva, A. C. F. (2015). Construction of a novel water quality index and quality indicator for reservoir water quality evaluation: a case study in the Amazon region. Journal of Hydrology, 522, 674-683.

Lumb, A., Sharma, T. C., \& Bibeault, J. F. (2011). A review of genesis and evolution of water quality index (WQI) and some future directions. Water Quality Exposure and Health, 3(1), $11-24$.

Mariano, A. P., Silva, A. J da, Oliveira, V. J. A. de, \& Angelis, D. de F. de (2010). Avaliação da dispersão de efluente líquido de refinaria de petróleo. Engenharia Sanitária e Ambiental, 15, 251-256.

Meador, M. R., \& Goldstein, R. M. (2003). Assessing water quality at large geographic scales: relations among land use, water physicochemistry, riparian condition, and fish community structure. Environmental Management, 31(4), 05040517.

Ministry of Environment (1996). Water quality status reports British Columbia. Lands and Parks, Water Quality Section, Victoria.

Mostafaei, A. (2014). Application of multivariate statistical methods and water-quality index to evaluation of water quality in the Kashkan River. Environmental Management, 53(4), 865-881.

Moura, V. M., Brito, S. M. O., \& Silva, A. B. (2013). Avaliação dos Parâmetros Indicadores da Qualidade da Água para Verificar o Estado de Conservação das Represas do Rio Ipitanga, Salvador, BA, Brasil. Revista Virtual de Quimica, 5(5), 869-890.

Nelson, E. J., \& Booth, D. B. (2002). Sediment sources in an urbanizing, mixed land-use watershed. Journal of Hydrology, 264(1), 51-68.

Obregón, G. O., Marengo, J. A., \& Nobre, C. A. (2014). Rainfall and climate variabilityy: long-term trends in the Metropolitan Area of Sao Paulo in the 20th century. Climate Research, 61, 93-107.

Oliveira, B.S.S., \& Cunha, A.C. (2014). Correlation between water quality and precipitation variability in the Southern State of Amapá. Revista Ambient Água, 9(2) Taubaté.

Oliveira, J. P., Santos, R. N. D., \& Boeira, J. M. (2012). Genotoxidade e Análise Físico-Químicas das Águas do Rio dos Sinos (RS) usando Allium cepa Eichhornia crassipes como bioindicadores. BBR - Biochemistry and Biotecnology Reports, 1(1), 15-22.

Pesce, S. F., \& Wunderlin, D. A. (2000). Use of water quality indices to verify the impact of Córdoba City (Argentina) on Suquía River. Water Research, 34(11), 2915-2926.

Pinto Filho, J. L. O., Santos, E. G., \& Souza, M. J. J. B. (2012). Proposta de Índice de Qualidade de Água para a Lagoa do Apodi, RN, Brasil. Holos Environment, 2, 69-76.

PNMA II. (2005). Ministério do Meio Ambiente, Secretaria do Estado do Meio Ambiente e Desenvolvimento Sustentável de Minas Gerais. Programa Nacional de Meio Ambiente. Sub- 
componente monitoramento da qualidade da água. Sistema de cálculo da qualidade da água (SCQA), 1-14.

Rodrigues, G. S. (1998). Avaliação de impactos ambientais de pesquisas. Fundamentos, princípios e introdução à metodologia (p. 66). Jaguariúna: EMBRAPA, CNPMA.

Salla, S., \& Ghosh, S. (2014). Assessment of water quality parameters of lower lake Bhopal. Archives of Applied Science Research, 6(2), 8-11.

Sharma, M.K., Jain, C.K., \& Singh, O. (2014).Characterization of point sources and water qualitiy assessement of River Hindon using water quality index. Journal of Indian Water Resources Society, 34(1).

Singh, P.K., Tiwari, A. K., \& Mahato, M. K. (2013). Qualitative Assessment of Surface water of West Bokaro Coalfield, Jharkhand by using water quality index method. International Journal of ChemTech Research, 5(5).

Skoulikidis, N., \& Amaxidis, Y. (2009). Origin and dynamics of dissolved and particulate nutrients in a minimally disturbed Mediterranean river with intermittent flow. Journal of Hydrology, 373(1), 218-229.
Spearling, M.V. (2005). Princípios do tratamento biológico de águas residuárias. Introdução à qualidade das águas e ao tratamento de esgotos. Departamento de Engenharia Sanitária e Ambiental - UFMG, v(1).

Strieder, M. U., Ronchi, L. H., Stenert, C., Scherer, R. T., \& Neiss, U. G. (2006). Medidas biológicas e índices de qualidade de água de uma microbacia com poluição urbana e de curtumes no sul do Brasil. Acta Biológica Leopondensia, 28(1), 17-24.

Teixeira, Z., Teixeira, H., \& Marques, J. C. (2014). Systematic processes of land use/land cover change to identify relevant driving forces: Implications on water quality. Science of the Total Environment, 470, 1320-1335.

Toledo, L. G., \& Nicolella, G. (2002). Índice de Qualidade da água em microbacia sob uso agrícola e urbano. Scientia Agricola, 59(1), 181-186.

Zanini, H. L., Amaral, L. A., Zanini, J. R., \& Tavares, L. H. S. (2010). Caracterização da água da microbacia do córrego rico avaliada pelo índice de qualidade de água e de estado trófico. Engenharia Agrícola, 30(4), 732-741. 